\title{
Monuments of Compassion
}

\author{
Linda Brant \\ Saybrook University, United States of America \\ Ibrant@saybrook.edu
}

\begin{abstract}
The term 'monument of compassion' is introduced to describe the essential features of the Monument To Animals We Do Not Mourn, as well as other animal monuments. Installed in Hartsdale Pet Cemetery in New York, The Monument To Animals We Do Not Mourn is unconventional in its representation of a marginalized group (farm animals), its challenge to dominant cultural narratives concerning this group, its interactivity, and its atypical location. It is an artist-driven, dialogic monument of dissent, offering cemetery visitors the opportunity to consider the suffering of farm animals in the same space that they mourn their beloved companion animals. The monument extends compassion to farm animals and affirms their value as individual beings, worthy of a full and natural life. Visitors who resonate with the monument's message are invited to leave a stone at its base. As the stones accumulate, they will be collected and used to create another monument of compassion for typically unmourned animals.
\end{abstract}

Keywords: monument of compassion, animals, Hartsdale, pet cemetery, antimonument

To cite this article:

Brant, L. (2020) Monuments of Compassion, The Journal of Public Space, 5(4), 22I-230, DOI I0.3289|/jps.v5i4.|42I

This article has been reviewed by the Editors and accepted for publication in The Journal of Public Space. This work is licensed under a Creative Commons Attribution - Non Commercial 4.0 International License https://creativecommons.org/licenses/by-nc/4.0/ 


\section{Introduction}

On October 26, 2018, a long-term project of mine was realized when the installation crew from Presbrey-Leland Monument Company arrived at Hartsdale Pet Cemetery in New York to install the Monument To Animals We Do Not Mourn. Funded by individual donations and multi-year grants from the Culture and Animals Foundation, the monument was over four years in the making. It now stands in middle of Hartsdale Pet Cemetery, near the 1923 War Dog Memorial. Hartsdale Pet Cemetery is the oldest pet cemetery in the United States, its origins dating back to 1896. It is home to over 80,000 animals, including dogs, cats, horses, reptiles, birds, and humans (petcem.com). Known as the Peaceable Kingdom, Hartsdale Pet Cemetery is open to all species; yet until recently, there was no monument recognizing farm animals there.

The Monument To Animals We Do Not Mourn seems both in and out of place among the thousands of companion animal graves that surround it at Hartsdale Pet Cemetery. Its traditional appearance blends unobtrusively with the existing gravestones in the cemetery. But its subject disrupts and unsettles, asking visitors to consider their relationships with farm animals in the same place that they mourn their beloved pets. The aim of this paper is to describe the Monument To Animals We Do Not Mourn, its strategic placement in Hartsdale Pet Cemetery, its symbolism, and its interactive potential. While it shares features of the contemporary anti-monument (Clark, 2017; Stevens, Franck and Fazakerley, 2018; Young, 1992, 1996) and neomonument (Clark, 2017), the Monument To Animals We Do Not Mourn is perhaps more aptly described as a monument of compassion (E. Greene 2019, pers. comm., 5 November) as it recognizes the suffering of billions of farm animals and acknowledges the reality of their individual lives and deaths.

I begin by outlining a working definition of monuments of compassion and presenting a few examples of animal monuments that might be described as such. I follow with a detailed description of the Monument To Animals We Do Not Mourn, its key features and strategic placement.

\section{Types of Monuments \\ Traditional}

Traditional monuments are familiar to almost everyone. Towering structures of bronze or stone, they are the focal points of myriad public parks and town squares. Often heroic and self-aggrandizing, traditional monuments celebrate the ideals and triumphs of a nation, state, or city (Young, 1996, p. 135). Traditional monuments are often figural statues commemorating generals, commanders, presidents or famous battles. They typically convey the discourses of dominant social or political groups.

Counter-monuments, Anti-monuments, and Neomonuments In recent decades, the terms counter-monument, anti-monument and neomonument have been proposed by scholars to describe public works that significantly depart in style, meaning or form from traditional monuments (Clark, 20I7; Stevens, Franck and Fazakerley, 2018; Young, 1992, 1996). Nontraditional monuments began to emerge with increased frequency during the latter part of the twentieth century, as artists sought new ways to address the realities within which they lived. In post-World War II Germany, artists began to design Holocaust memorials using alternative techniques, materials and approaches. These and other counter-monuments, as James Young (1992, 
1996) originally described them, "challenge the conventional premises of the monument" (1996, p. 240). In his 1992 essay entitled The counter-monument: Memory against itself in Germany today, Young describes examples of contemporary countermonuments, emphasizing the characteristics of impermanence, public engagement, disruption of public space, and negative form.

Drawing on the work of Young (1992), Stevens, Franck and Fazakerley (2018, p. 772) have proposed the term 'anti-monumental' to describe monuments that differ from traditional commemorative works in the following respects: subject matter, form, location, visitor experience or meaning. Unlike traditional monuments, anti-monuments convey the narratives and discourses of under-represented groups. Often temporary or ephemeral, anti-monuments are constructed from a wide range of materials. Rather than being located in prominent public spheres, anti-monuments are often located in unexpected spaces. Anti-monuments encourage an active response from the public. While traditional monuments are explicit in their meaning, anti-monuments are more likely to be ambiguous or open to interpretation.

Stevens, Franck and Fazakerley (20I8, p. 7I8) also propose the term 'dialogic' to describe a specific type of counter-monument that has been installed in close proximity to an existing monument, providing a commentary or critique of the existing monument. As an example of a dialogic monument, the authors cite Henry Moore's Goslar Warrior, installed in 1974 in Goslar, Germany. Moore's monument serves as a countermonument to the World War I Monument, Goslar Hunter. Both monuments are installed along Goslar's defensive wall, with each offering a different narrative concerning the war and its effects.

Clark (2017) proposes the word 'neomonument' to describe conceptual art works that challenge the public to think more deeply about subjects of concern. He asserts that neomonuments are artist-driven, rather than being responses to the prerequisites of larger public or private organizations. Neomonuments "come from an artist's desire to highlight a politically directed question in a way that uses their creative talents to give impact to that question"(p. 7I). They are statements of "reasoned dissent" that prompt thinking (p. 10). Examples of neomonuments include Tue Greenfort's Diffuse Einträge and Marc Quinn's Alison Lapper, Pregnant (Clark, 2017, pp. 77-II3).

\section{Monuments of Compassion}

I define 'monuments of compassion' as public works that respond to the suffering of others and seek to promote a shift in perspective, attitude, or behavior. Flexibility is needed in classifying monuments of compassion, since the circumstances and intentions surrounding certain monuments may not be fully known. Like neomonuments, monuments of compassion can be artist-driven responses to social, political or environmental conditions (Clark, 2017). Like anti-monuments, monuments of compassion may depart from traditional methods of representation in terms of subject matter, form, location, visitor experience or meaning (Stevens, Franck and Fazakerley, 2018). I use the terms 'counter-monument,' and 'dialogic monument,' to describe monuments that have been strategically installed in the vicinity of other monuments in order to suggest a contrasting narrative (Clark, 2017; Stevens, Franck and Fazakerley, 2018; Young, 1992, 1996). 


\section{Animal Monuments of Compassion}

One of the earliest known examples of an animal monument of compassion is the Brown Dog Statue, by Joseph Whitehead. The statue was commissioned by antivivisectionists and installed in 1906 in response to the inhumane treatment of a laboratory dog by a professor and his colleagues at University College of London (Cain, 2013). The original Brown Dog Statue featured a lifelike bronze terrier sitting attentively on top of a public drinking fountain. The monument was installed in the London Metropolitan Borough of Battersea, with a plaque bearing the following inscription:

In memory of the brown terrier dog done to death in the laboratories of University College in February 1903 after having endured vivisection extending over more than two months and having been handed over from one vivisector to another til death came to his release. Also in memory of the 232 dogs vivisected at the same place during the year 1902. Men and women of England how long shall these things be?

(Lansbury, 1985, p. 42).

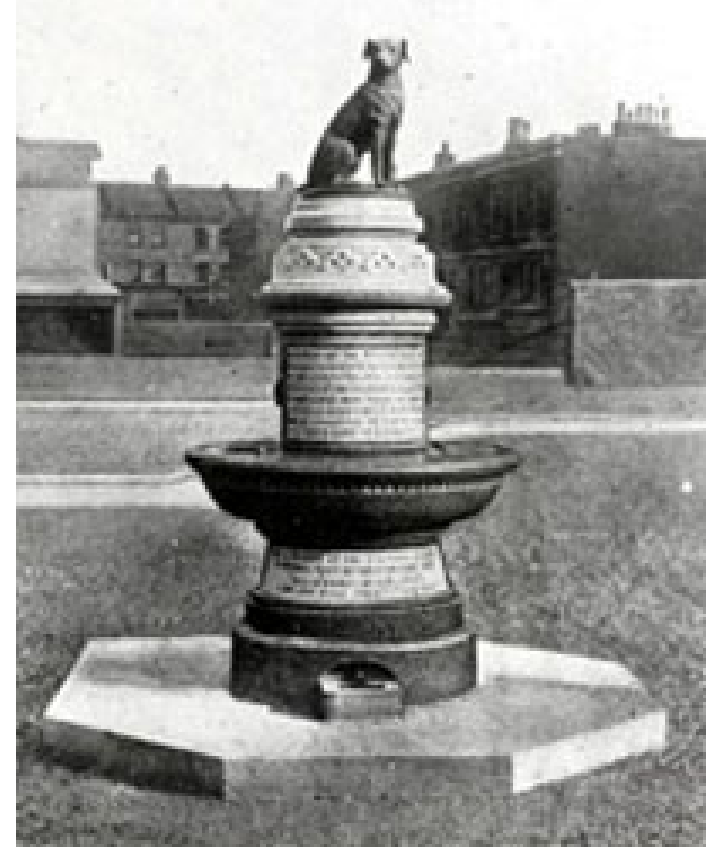

Figure I. Original brown dog statue (1906). Source: public domain

The original Brown Dog Statue, an unequivocal monument of dissent, was tremendously controversial, triggering numerous riots. The statue was "an indictment of the way humans had misused nonhuman animals, particularly those defined as possessing qualities of loyalty: dogs" (Kean, 2003 p.36I). In 1907, outraged medical students reportedly stormed the monument in an attempt to tear it down (Mason, 1997). The ongoing violence and disruption led to its removal in 1910. In 1985, 75 years after the removal of the original Brown Dog Statue, a new memorial to the brown dog was installed in Battersea Park where it remains today (Cain, 2013). Both the original (1906) and the new (1985) Brown Dog Statues are the products of artist-community collaborations. 
They are explicit in their protests against vivisection and in their expressions of compassion for animal victims.

Ongoing concern with the suffering of animals in medical settings is evidenced by the placement of a monument dedicated to laboratory animals in Hartsdale Pet Cemetery in New York. Installed in the 1990s by the American Fund for Alternatives to Animal Research, the inscription reads, "In memory of the millions of animals whose lives are taken in research and testing." This simple monument of compassion is now located adjacent to The Monument To Animals We Do Not Mourn.

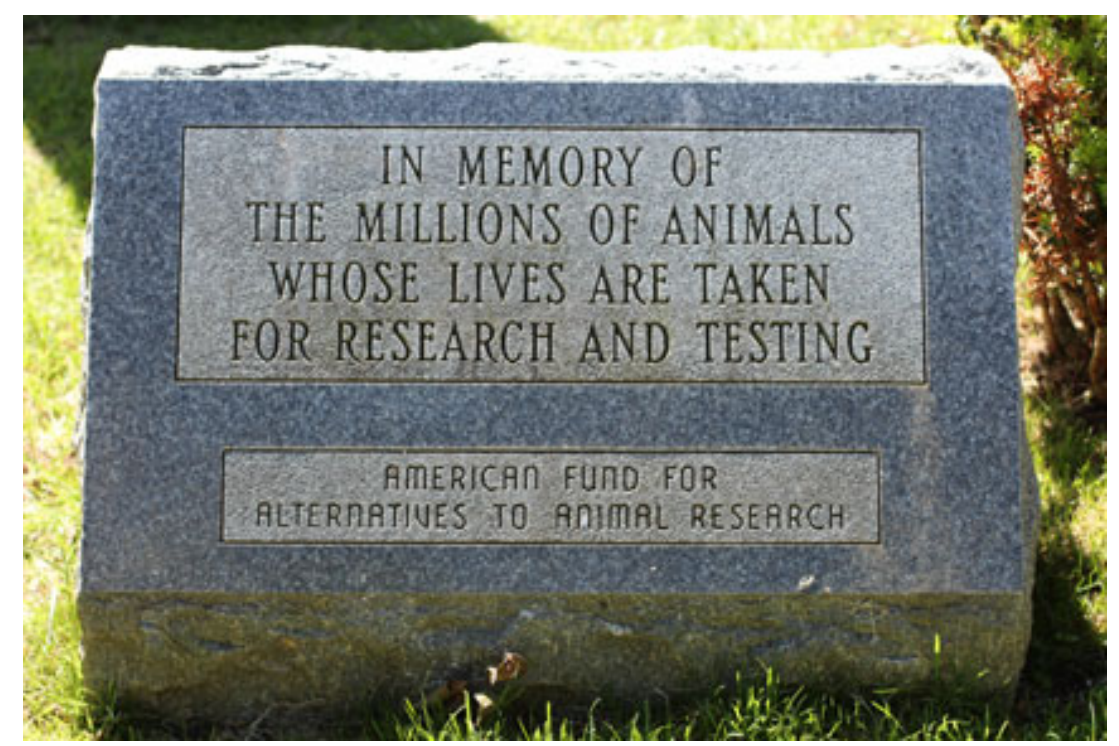

Figure 2. Monument for laboratory animals in Hartsdale Pet Cemetery, NY. Source: Linda Brant

Contemporary monuments of compassion may take less conventional forms, such as temporary installations in public spaces. The Black Bear Memorial, which took place at Lake Eola Park in Orlando, Florida in 2015, is one such example. The installation served as a protest against a black bear hunt that was held in the state. During the hunt, approximately 300 bears were slaughtered in the Florida forests, a third of which were lactating females (Large crowd gathers, 2015). The installation featured interactive gravestones, encouraging attendees to write personalized messages in chalk. Visitors lined up to place flowers, pictures, and other symbolic objects in an open coffin representing the hundreds of bears that were killed by hunters. The installation recognized the suffering of the slain bears, activated public engagement, and encouraged expressions of anger, sadness, and grief.

Monuments of compassion can be permanent or temporary, located in urban or remote places, portray a range of subjects, and take an almost infinite variety of forms. They are often unsettling or disturbing to the viewer, because they shine a light on the underbelly of a culture, mirroring the inevitable flaws in prevailing social systems. 


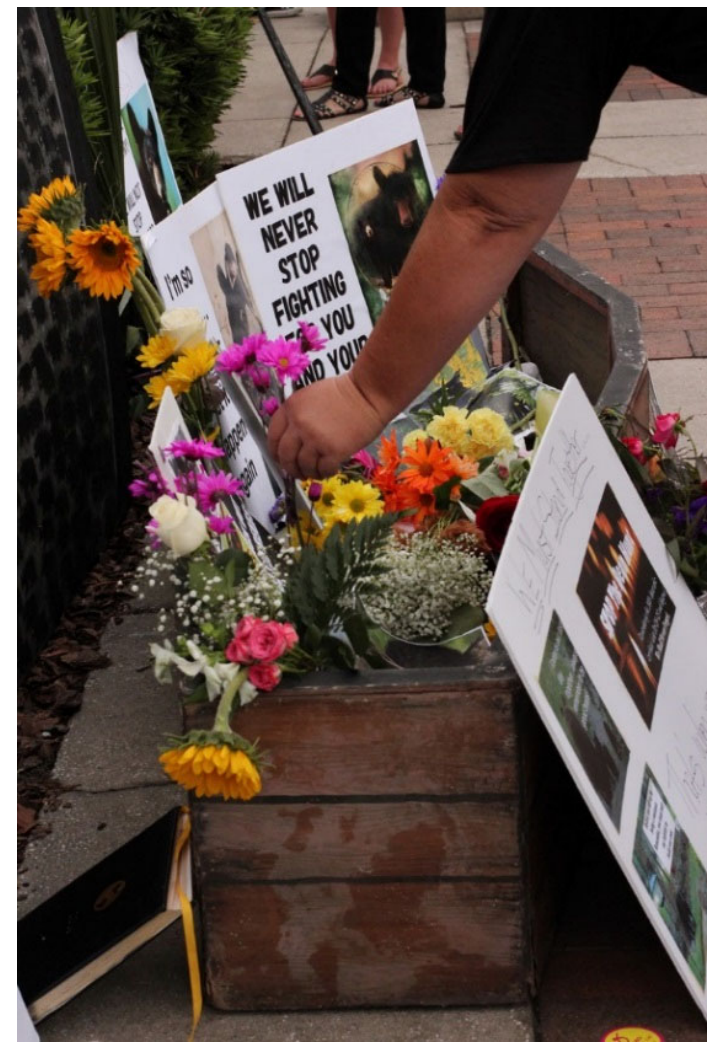

Figure 3. Coffin as ephemeral monument of compassion, Black Bear Memorial, Orlando, FL (2015). Source: Linda Brant

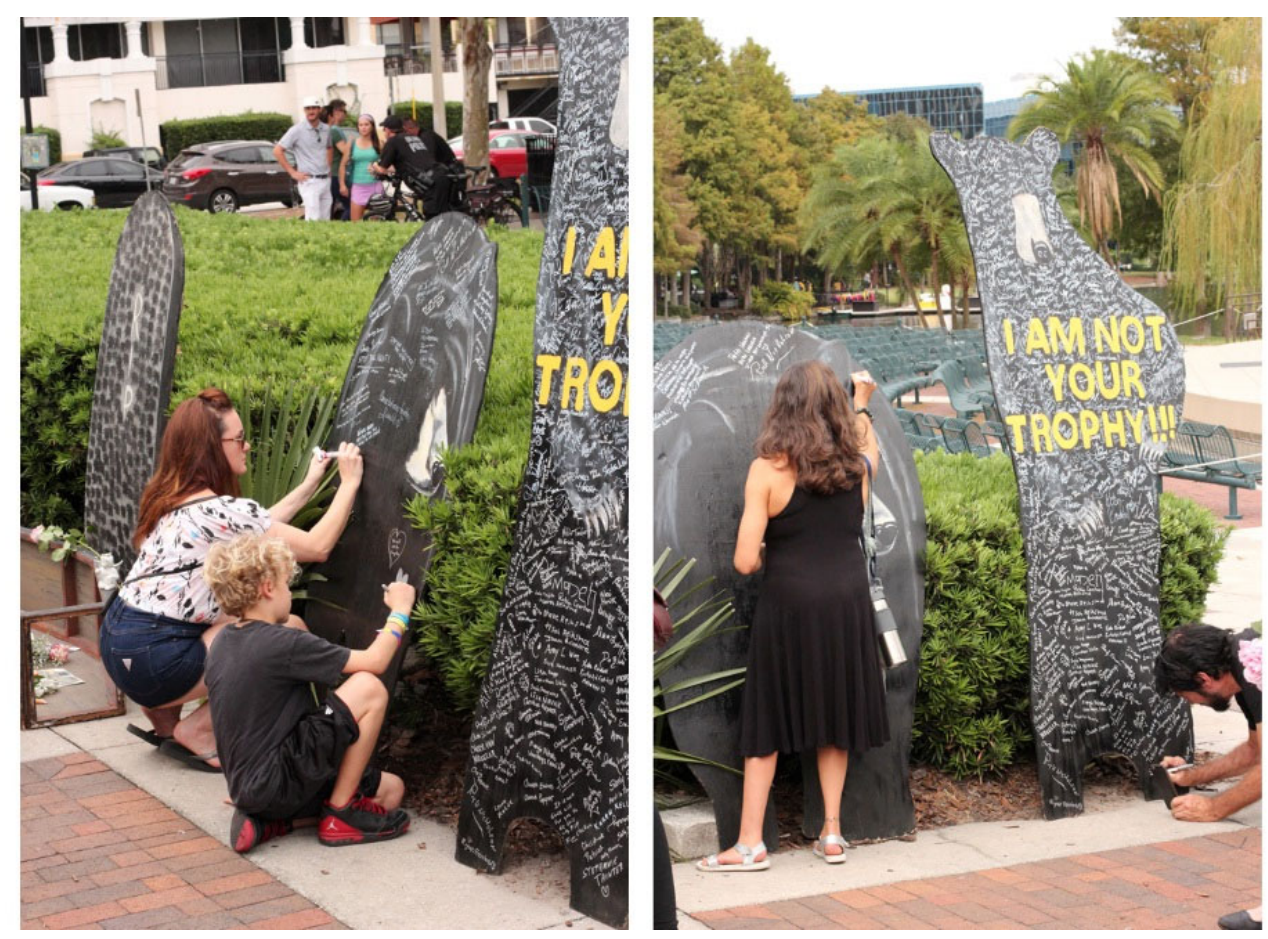

Figure 4. Interactive gravestones as ephemeral monuments of compassion, Black Bear Memorial, Orlando, FL (2015). Source: Linda Brant 


\section{Monument To Animals We Do Not Mourn}

The Monument To Animals We Do Not Mourn is a monument of compassion that shares features with traditional monuments, anti-monuments, and neomonuments. An artist-driven monument of dissent, it is constructed with traditional materials - granite and bronze. Created in response to the unimaginable suffering of individual farm animals, the monument calls attention to a category of animals that is effectively invisible and rarely memorialized. The monument also departs from tradition in its interactivity, and its placement in Hartsdale Pet Cemetery.

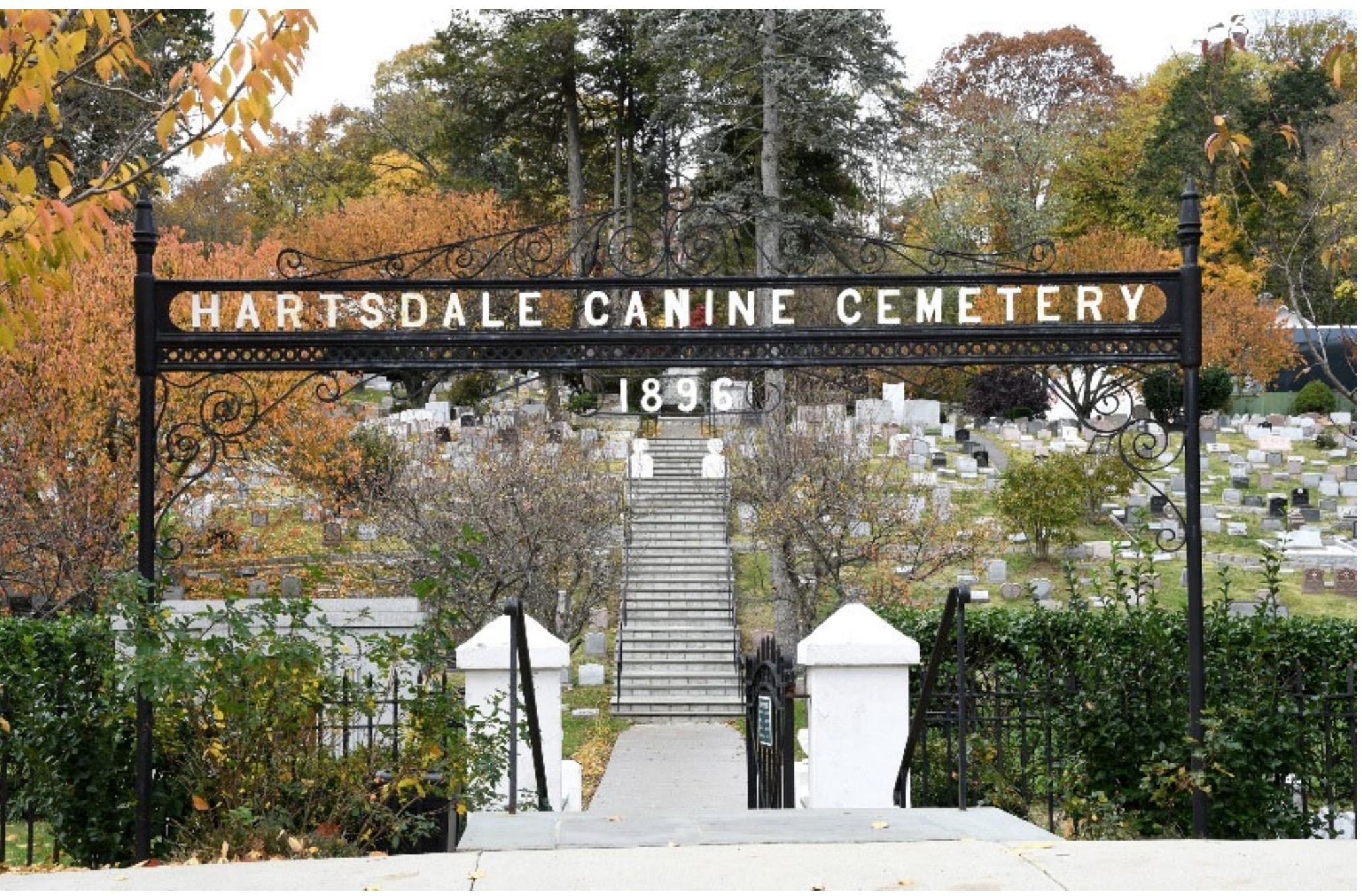

Figure 5. Hartsdale Pet Cemetery (20I8). Source: Edward Watkins

A dialogic strategy was used in the selection of Hartsdale Pet Cemetery as the installation site for the Monument To Animals We Do Not Mourn. What better place to put a monument for unmourned animals than in a cemetery that is full to the brim with monuments for treasured companion animals? The Monument To Animals We Do Not Mourn represents a contrast to the existing gravestones at Hartsdale Pet Cemetery and points to obvious discrepancies in our perceptions and treatment of different types of animals. The monument communicates a simple yet disturbing reality, representing 
and revealing the hidden presence of the billions of animals that are killed in slaughterhouses worldwide (Kean, 20I I).

The monument's durable materials (granite, bronze, crystal) stand in contrast to a throw-away society and the commonly held view that the lives of certain types of animals are disposable. Made of bethel white granite, the monument features a gently curving upright tablet with a cast bronze cattle skull in the middle. A hand-faceted quartz crystal is carefully placed in the position of the skull's third eye. In Eastern traditions, the third eye represents wisdom and perception beyond ordinary sight (Song, 2002).

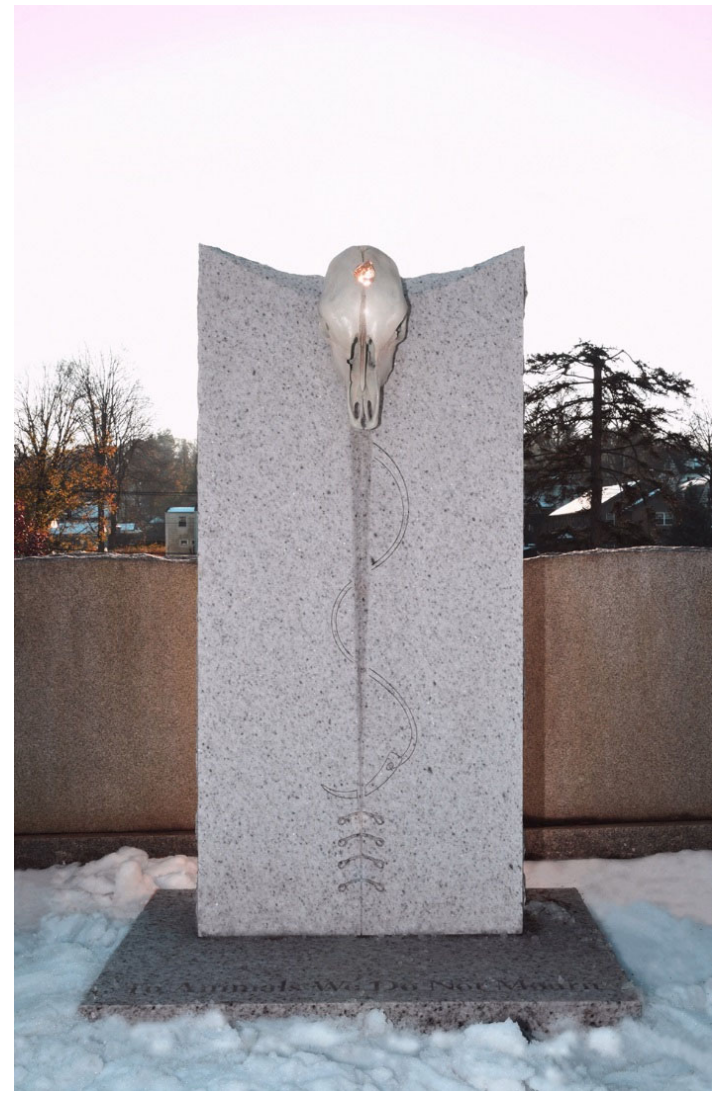

Figure 6. Monument To Animals We Do Not Mourn (2018). Source: Edward Watkins

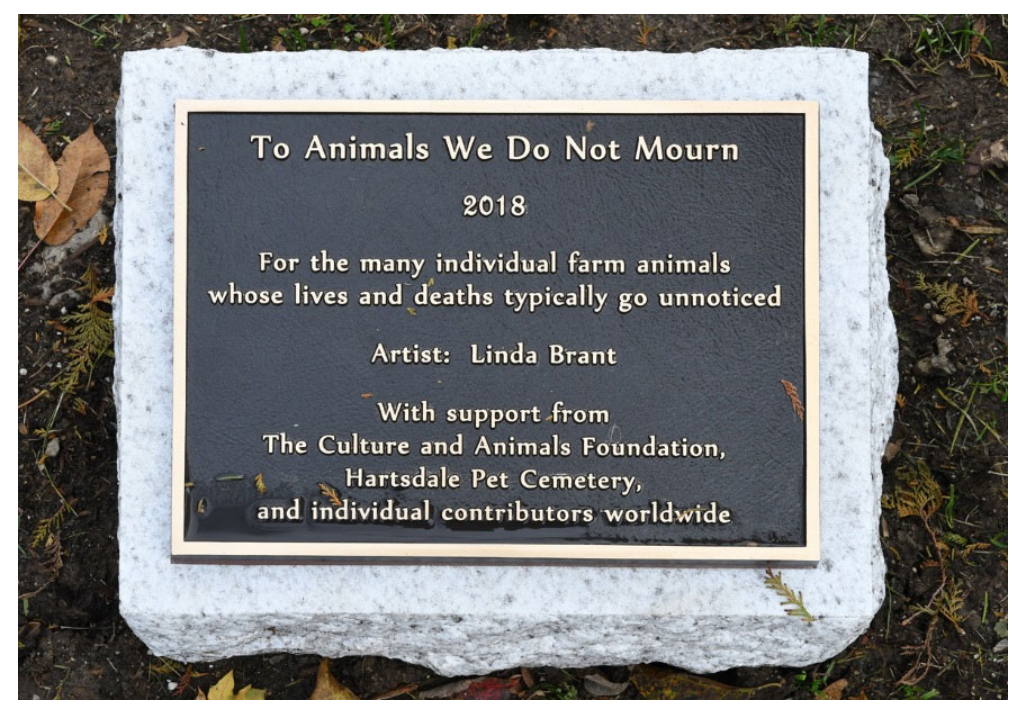

Figure 7. Plaque for Monument To Animals We Do Not Mourn (2018). Source: Edward Watkins

The Monument To Animals We Do Not Mourn reveals a painful irony in its critical placement of the crystal. When cattle are slaughtered, they are first shot between the eyes with a captive bolt stunner, leaving a characteristic hole in the skull. Paradoxically, the site of this injury corresponds with that of the metaphorical third eye. The quartz crystal functions as a symbol, transforming the place of pain into a call for compassion. Because the monument faces due west, the rays of the sun pass directly through faceted crystal in the skull each morning at sunrise, creating a brilliant glow.

A hand carved crack runs down the middle of the monument, denoting injury and echoing a similar crack in the skull above it. A curving thread leads the viewer's eye from the skull to the base of the monument where an etched needle and four carved 
stitches suggest the process of mending a wound. This 'sewn' portion of the monument represents the work that must be done to extend the range of human compassion to farm animals. The top of the bronze skull is 55 inches high, which is approximately the same height as a young cow or steer at the time of slaughter. In front of the monument, a bronze plaque reads, "For the many individual farm animals whose lives and deaths typically go unnoticed.'

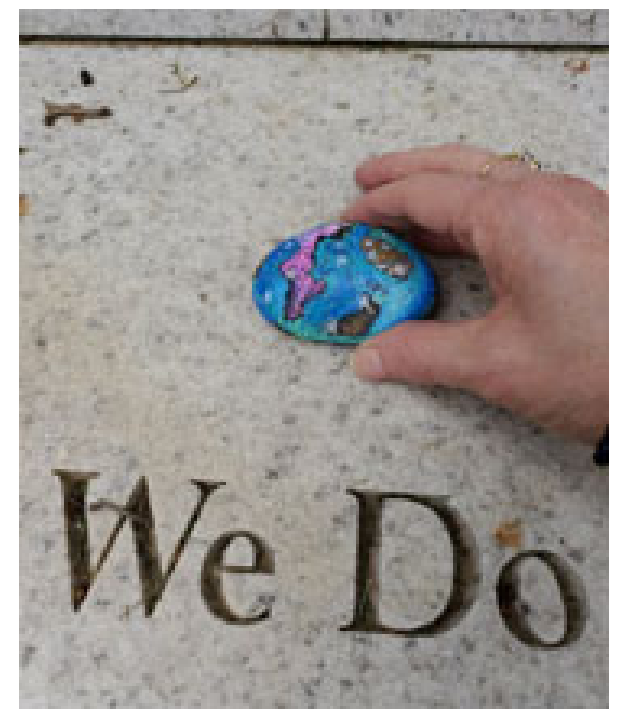

Figure 8. Visitor leaving stone at base of Monument To Animals We Do Not Mourn (2018) Source: Linda Brant

Visitors who resonate with the monument's message of compassion can demonstrate solidarity by leaving a stone at the base of the monument. The custom of leaving stones on graves dates back to ancient times and is most strongly associated with the Jewish tradition. Leaving a stone on a grave is a tangible act of remembrance of the deceased, showing that the individual is not forgotten (Reik, 1964). Similarly, leaving a stone on the Monument To Animals We Do Not Mourn is an expression of the visitor's compassionate presence. As the stones accumulate, they will be collected and used to create another monument for unmourned animals.

\section{Conclusion}

The term 'monument of compassion' was proposed to describe the essential features of the Monument To Animals We Do Not Mourn, as well as other animal monuments. While traditional in appearance, the Monument To Animals We Do Not Mourn is unconventional in its representation of a marginalized group (farm animals), its challenge to dominant cultural narratives concerning this group, its interactivity, and its atypical location. It is an artist-driven, dialogic monument of dissent, summoning viewers to consider their views of farmed animals in a landscape full of companion animal graves at Hartsdale Pet Cemetery. Visitors have the opportunity to express their compassion and participate in the making of a future monument by leaving a stone at the monument's base. The monument recognizes the lives and deaths of farm animals, affirms their value 
as individual beings, and seeks to inspire a shift in perception, attitude and behavior with respect to these individuals.

\section{Acknowledgments}

Many thanks to the Culture and Animals Foundation for their financial support of the Monument To Animals We Do Not Mourn. I would also like to express my great appreciation to cultural anthropologist Eric Greene, founder of the Green Pet-Burial Society, a project of Family Spirals, and to cultural historian Dr. Hilda Kean FRHistS, for their insightful contributions and comments on this manuscript.

\section{References}

Cain, J. (2013) The Brown Dog in Battersea Park. London: Euston Grove Press.

Clark, D. (2017) 'The neo-monument: Monuments of dissent and their emergence in Western culture in the late 20th and early 2 I st century', Ph.D. thesis, Bath Spa University, United Kingdom.

Greene, E. (2019) Personal communication, 5 November.

Hartsdale Pet Cemetery. Available at https://www.petcem.com (Accessed: 22 August, 2020).

Kean, H. (2003) 'An exploration of the sculptures of Greyfriars Bobby, Edinburgh, Scotland, and the Brown Dog, Battersea South London, England', Society and Animals, I (4), pp.353-373.

Kean, H. (20II) 'Traces and representations: Animal pasts in London's present', The London Journal, 36(I), Pp. 54-7I.

Kretzer, M. (20I4) 'PETA's roadside memorials pay homage to more than 500 slain animals.' Available at: https://www.peta.org/blog/roadside-memorials/(Accessed: 5 December, 2019).

Lansbury, C. (1985) The old brown dog: Women, workers and vivisection in Edwardian England. Madison, WI: University of Wisconsin Press.

'Large crowd gathers for black bear memorial at Lake Eola' (2015), I November. Available at: https://www.wftv.com/news/local/large-crowd-gathers-black-bear-memorial-lakeeola/27002227 (Accessed: 10 November 2015).

Mason, P. (1997) The Brown Dog affair. London: Two Sevens Publishing.

Reik, T. (1964) Pagan rites in Judaism. New York: Farrar, Straus \& Co.

Song, C. (2002) Third-eye theology: Theology in formation in Asian settings. Eugene, OR: Wipf and Stock Publishers.

Stevens, Q., Franck, K. A. \& Fazakerley, R. (2018) 'Counter-monuments: The anti-monumental and the dialogic', The Journal of Architecture, 23(5), pp. 718-739.

Young, J. E. (1992) 'The counter-monument: Memory against itself in Germany today', Critical Inquiry, 18(2), pp.267-296.

Young, J. E. (1996) 'Memory/monument' in Nelson, R.S. and Shiff, R.(eds), Critical terms for art history. Chicago: University of Chicago Press, pp. 234-250. 